\title{
RESPON HISTOLOGIS TUBUH KODOK (Rana catesbeiana Shaw) TERHADAP INFEKSI BAKTERI PATOGEN DAN POTENSI Saccharomyces cerevisiae SEBAGAI IMUNOSTIMULAN
}

\author{
Taukhid, Pipik Taufik, dan Honorius Mundriyanto
}

\begin{abstract}
ABSTRAK
Penelitian ini bertujuan untuk mengetahui respon histologis tubuh kodok (Rana catesbeiana Shaw) terhadap infeksi bakteri patogen serta potensi ekstrak Saccharomyces cerevisiae terhadap peningkatan respon imunitas tubuh kodok yang diberikan melalui pakan didahului dengan priming. Uji respon histologis dilakukan melalui infeksi buatan terhadap bakteri patogen Aeromonas hydrophila pada dosis $10^{6}$ dan $10^{8}$ cfu/ekor. Pengamatan dilakukan terhadap gejala klinis dan respon histopatologis. Sedangkan uji potensi imunostimulan terhadap imunitas kodok dilakukan melalui perendaman dalam larutan tersebut pada konsentrasi $100 \mathrm{mg} / \mathrm{L}$ selama 60 menit sebagai priming, kemudian dilanjutkan dengan booster I \& II yang diberikan melalui pakan. Dosis imunostimulan yang diberikan adalah (A) $500 \mathrm{mg} / \mathrm{kg}$, (B) $750 \mathrm{mg} / \mathrm{kg}$, (C) $1.000 \mathrm{mg} / \mathrm{kg}$ pakan, dan (D) tanpa imunostimulan sebagai kontrol. Parameter yang diamati meliputi diferensial leukosit, aktivitas fagositik dan titer antibodi terhadap bakteri $A$. hydrophila. Hasil percobaan menunjukkan bahwa model infeksi bakteri pada kedua konsentrasi tersebut tidak virulen, meskipun terjadi kerusakan jaringan. Hal ini diindikasikan dengan gambaran respon histopatologis organ hati dan ginjal yang menunjukkan adanya kerusakan seperti degenerasi lemak, melanisasi, nekrosis, dan piknosis. Sedangkan hasil percobaan peningkatan imunitas tubuh kodok menunjukkan bahwa pemberian imunostimulan dapat meningkatkan kekebalan non-spesifik yang diindikasikan dengan meningkatnya proporsi leukosit fungsional (limfosit dan netrofil), aktivitas fagositosis, serta titer antibodi.
\end{abstract}
ABSTRACT: Histological response of bullfrog (Rana catesbeiana Shaw) against bacterial infection artificially, and potency of Saccharomyces cerevisiae as immunostimulant. By: Taukhid, Pipik Taufik, and Honorius Mundriyanto

The experiment has an aim to study bullfrog histological response against pathogenic bacteria which were infected artificially, and the potency of applying immunostimulant (S. cerevisiae) to induce non-specific immune response of bullfrog. Challenge test was carried out by artificial infection with pathogenic bacteria, A. hydrophila at concentrations of $10^{6} \mathrm{cfu}$ and $10^{8} \mathrm{cfu}$ per frog. Parameters examined were clinical signs and histopathologicaly response especially on the liver and kidney. Another trial, was carried out to know the potency of immunostimulant by immersing the frog into immunostimulant at a concentration of $100 \mathrm{mg} / \mathrm{L}$ for 60 minutes as priming, then continued by booster I \& /I which were administered via feed. Doses of immunostimulant applied were (A) $500 \mathrm{mg} / \mathrm{kg}$, (B) $750 \mathrm{mg} / \mathrm{kg}$, (C) $1000 \mathrm{mg} / \mathrm{kg}$ feed, and (D) without immunostimulant as a control. Parameters examined were differential leucocyte, phagocytic activity, and antibody titre against $\mathbf{A}$. hydrophila. The results indicated that artificially infection to the bacterial model at defined doses was not virulence, although, histopathological changes were found on the liver and kidney i.e. fat degeneration, melanization, necrotic, piknotic, and kariorexis. Applying immunostimulant was found a promising strategy to induce non-specific immunity wich was indicated by increasing of leucocyte proportion (lymphocyte and netrophyl), phagocytic activity, and antibody titre.

\section{KEYWORDS: bullfrog, histopathology, immunostimulant, bacterial}

\section{PENDAHULUAN}

Budi daya di Indonesia kodok benggala, Rana catesbeiana Shaw telah berlangsung sejak pertengahan tahun delapan puluhan di beberapa daerah, terutama di Pulau Jawa (Mundriyanto et al., 1993). Kodok jenis ini mempunyai sifat yang lebih jinak, lebih adaptif terhadap lingkungan buatan, dan mudah dilatih untuk mengkonsumsi pakan buatan serta umumnya berukuran lebih besar daripada kodok lokal.

Akhir-akhir ini sering dilaporkan adanya kematian kodok akibat infeksi jasad patogen. Umumnya kodok yang sakit menunjukkan gejala luka bercak kemerahan (red plague) dan gripis-gripis pada jari kaki,

\footnotetext{
") Peneliti pada Balai Penelitian Perikanan Air Tawar, Sukamandi
} 
dan penyakit ini menyerang pada seluruh stadia hidup kodok. Meskipun agen penyebab penyakit tersebut belum teridentifikasi secara pasti, namun dari beberapa jenis bakteri yang memiliki prevalensi tinggi terisolasi dari kodok yang mati dan moribund adalah spesies Aeromonas hydrophila dan Pseudomonas sp. (Crumlish \& Inglish, 1999). Somsiri \& Soontornvit (2000) telah mengisolasi bakteri dari kodok (R. tigrina) sakit yang berasal dari 173 peternak dengan gejala klinis: pendarahan pada kulit dan/atau organ-organ dalam, mata kabur atau putih, luka pada kulit, dan hilang nafsu makan. Dari hasil isolasi diperoleh jenis bakteri Aeromonas spp., Achromobacter sp., Citrobacter freundii, Flexibacter columnaris, Pseudomonas spp., Proteus spp., Serratia sp., Staphylococcus sp., dan Streptococcus. Namun dari beberapa jenis bakteri tersebut, prevalensi paling tinggi adalah dari kelompok Aeromonas yaitu sebesar 51,67\%.

Peryakit dengan gejala klinis yang hampir serupa pada $R$. tigrina dapat mengakibatkan kematian antara 20-50\% (Kanchanakhan, 1998). Penyakit ini disebabkan oleh infeksi Tiger Frog Iridovirus (TFIV) yaitu virus dari famili Iridoviridae. Selanjutnya Kanchanakhan et al. (2000) mengisolasi virus tersebut dari 170 sampel kodok sakit dan didapatkan 70 isolat virus. Virus-virus tersebut mengakibatkan flek lisis cytopathic effect yang sama pada sel lestari Epithelioma Papulosim Cyprini (EPC) dan memiliki genom, serta karakter meristik-morfometrik yang sama pula. Tipe gen protein capsid dari virus tersebut adalah spesifik Ranavirus genus FV3, sehingga untuk sementara virus tersebut dinamakan Rana Tigrina Ranavirus (RTRV)

Penggunaan vaksin dalam akuakultur untuk mengurangi risiko infeksi jasad patogen sudah berkembang sejalan dengan perkembangan imunologi ikan, namun tidak ada vaksin yang efisien untuk melawan sejumlah penyakit infeksi potensial secara simultan. Antibiotik dan bahan-bahan kimia dapat pula digunakan untuk menghindari infeksi akut, tetapi penggunaan material tersebut secara terus-menerus akan menimbulkan dampak lingkungan yang kurang baik, munculnya generasi bakteri yang resisten, serta akan menurunkan reputasi produk akuakultur di pasaran (Subasinghe et al., 2000) terlebih lagi apabila produk tersebut adalah komoditas ekspor seperti kodok.

Informasi tentang sistem kekebalan pada species ranid sudah dilaporkan oleh Crumlish \& Inglish (1999) dan Taukhid et al. (2000), demikian pula dengan potensi imunogenik serta prospek penggunaan beberapa jenis imunostimulan seperti b-Glucan (Crumlish \& Inglish, 1999) dan Lipopolisakarida (Taukhid et al., 2000) dalam kaitannya dengan strategi penanggulangan penyakit pada kodok.
Sejumlah materi biologis telah diketahui mempunyai potensi untuk menginduksi sistem kekebalan non-spesifik pada hewan, termasuk ikan dan udang; serta menunjukkan peningkatan ketahanannya secara simultan terhadap infeksi beberapa jenis patogen (Raa et al., 1992). Ragi (Saccharomyces cerevisiae) dengan produk akhir berupa glukan yang merupakan salah satu elemen struktural penting dari dinding sel adalah imunostimulan yang potensial, dan telah digunakan untuk merangsang mekanisme pertahanan non-spesifik pada organisme tingkat tinggi (Rosenberger, 1976 dalam Raa et al., 1992). Struktur molekul materi tersebut adalah polisakarida yang tersusun atas unit-unit glukosa dengan ikatan b-1,3 dan b-1,6 (Duffus et al., 1982 dalam Raa et al., 1992). Pada tumbuhan, glukan dapat merangsang produksi fitoaleksins yang merupakan bagian antibiotik dengan bobot molekul rendah, pada invertebrata akan mengaktifkan polifenoloksidase, dan pada tikus mampu meningkatkan mekanisme anti kanker (Robertsen et al., 1990).

Penelitian ini bertujuan untuk mengetahui respon histologis tubuh kodok terhadap infeksi bakteri patogen A. hydrophila melalui teknik infeksi buatan serta penggunaan ekstrak S. cerevisiae sebagai imunostimulan yang diberikan melalui pakan didahului dengan priming melalui perendaman.

\section{METODE PENELITIAN}

\section{Respon histopatologis tubuh kodok terhadap infeksi bakteri patogen}

Isolat bakteri yang digunakan sebagai sumber infeksi merupakan hasil screening sederhana terhadap 4 (empat) isolat bakteri yang diperoleh dari kodokkodok sakit di Instalasi Penelitian Perikanan Air Tawar, Depok dengan gejala klinis red leg. Screening tersebut dilakukan menurut teknik postulat Koch (Thrusfield, 1986); dan setelah diperoleh satu isolat tersangka selanjutnya diidentifikasi menurut Cowan \& Steells (1993).

Kandidat isolat terpilih kemudian dikultur secara in vitro pada media Tryptic Soy Agar (TSA) dan dipanen secara kering, dilarutkan dalam pelarut saline, diestimasi nilai densitas optik (OD) dari beberapa sediaan konsentrasi dengan bantuan spektrofotometer. Selain itu juga dilakukan total plate count bacteria secara konvensional, sehingga didapatkan satu formula matematis sebagai standar isolat bakteri tersebut dalam bentuk persamaan regresi linier yang menggambarkan hubungan antara nilai densitas optik dengan konsentrasi bakteri.

Kodok uji berukuran antara 50-60 g/ekor berasal dari satu populasi hasil pemijahan terkontrol di 
perbenihan Inlitkanwar, Depok. Aklimatisasi terhadap lingkungan baru dilakukan selama satu minggu sebelum perlakuan. Penggantian air baru dilakukan setiap tiga hari sekali, bersamaan pada saat sampling. Pakan yang diberikan selama percobaan berupa pakan komersial berbentuk pellet dengan rasio protein sebanyak $30 \%$, dan diberikan dua kali sehari sebanyak $3 \%$ dari bobot tubuh.

Rancangan percobaan yang digunakan adalah Rancangan Acak Lengkap (RAL) dengan 3 (tiga) perlakuan yaitu konsentrasi bakteri sebagai faktor utama. Infeksi buatan diberikan melalui penyuntikan secara intra muskular, yaitu (A) $10^{6} \mathrm{cfu},(B) 10^{8} \mathrm{cfu}$, dan $(C)$ satu perlakuan disuntik dengan saline $0,85 \%$ sebagai kontrol. Wadah percobaan berupa fiber glass berdiameter $0,5 \mathrm{~m}$ dan diisi kodok sebanyak 10 ekor/ wadah. Masing-masing perlakuan dilakukan pengulangan sebanyak 3 kali.

Pengamatan dilakukan secara berkala setiap 3 hari sekali sebanyak 5 kali terhadap gejala klinis, respon histopatologis pada organ hati dan ginjal, reisolasi bakteri dari organ yang luka (borok) dilanjutkan dengan identifikasi, serta mortalitas selama pengujian. Organ hati dan ginjal untuk keperluan pengamatan respon histopatologis diambil secara acak dari tiga ekor kodok yang diambil secara acak untuk masing-masing perlakuan setiap kali sampling (satu ekor per ulangan). Fiksasi dilakukan dalam larutan netral buffer formalin $10 \%$ dan pewarnaan dengan hematoksilin dan eosin.

\section{Potensi Saccharomyces cerevisiae sebagai imunostimulan}

Imunostimulan yang digunakan adalah ekstrak $S$. cerevisiae yang diperoleh dari hasil kultur in vitro. Kultur biakan dilakukan dalam media modifikasi Potato Broth Medium, diinkubasi pada suhu $28^{\circ} \mathrm{C}$ selama 48-72 jam, dan pemanenan dilakukan melalui teknik penyaringan dan sentrifugasi. Ekstraksi S. cerevisiae dilakukan melalui pemecahan sel dengan menggunakan alat sonikator pada amplitudo normal selama $4 \times 10$ menit dengan interval 5 menit. Pemampatan ekstrak imunostimulan dilakukan melalui teknik sentrifugasi dingin $\left(10^{\circ} \mathrm{C}\right)$ pada putaran 4.500 rpm, sedangkan konversi dan standardisasi sediaan dilakukan melalui teknik dehidrasi.

Kodok benggala yang digunakan dalam percobaan ini berukuran percil (10-15 g/ekor) berasal dari satu populasi hasil pemijahan terkontrol. Aklimatisasi terhadap lingkungan baru dilakukan selama satu minggu sebelum perlakuan. Ketinggian air dalam bak disesuaikan dengan tinggi dada kodok, disediakan tempat untuk mendarat, dan bak selalu ditutup $3 / 4$ bagian dengan plastik gelombang. Penggantian air baru dilakukan setiap dua hari sekali. Pakan yang diberikan selama percobaan berupa pakan komersial berbentuk pelet dengan rasio protein sebanyak $30 \%$, dan diberikan tiga kali sehari sebanyak $3 \%$ dari bobot tubuh.

Pemberian imunostimulan dilakukan melalui teknik perendaman dalam larutan yang mengandung ekstrak S. cerevisiae pada konsentrasi $100 \mathrm{mg} / \mathrm{L}$ selama 60 menit. Perendaman pertama tersebut merupakan priming yang bertujuan untuk memberikan memorizing terhadap materi imunostimulan, sedangkan pada kelompok kontrol direndam dalam air sumur dalam tempo yang sama. Setelah proses perendaman yang dilakukan secara pooling, kemudian kodok-kodok tersebut dipelihara dalam bak-bak fiber glass berdiameter 0,5 meter sesuai dengan hasil pengacakan dengan kepadatan masing-masing 10 ekor/bak

Pemberian imunostimulan berikutnya (booster) dilakukan sebanyak dua kali melalui pakan dan ditetapkan sebagai perlakuan. Dosis yang diterapkan yaitu: A (500 mg/kg pakan), B (750 mg/kg pakan), C (1.000 $\mathrm{mg} / \mathrm{kg}$ pakan), dan D (tanpa pemberian imunostimulan) sebagai kontrol. Masing-masing perlakuan dilakukan pengulangan sebanyak 3 kali.

Rincian jadwal perlakuan tersebut disajikan pada Tabel 1. Selama sepuluh hari sejak priming, kodok diberi pakan biasa; kemudian pada hari ke-11 sampai hari ke-15 diberi pakan sesuai perlakuan (booster I); pada hari ke-16--25 diberi pakan biasa, dan pada hari ke-26--30 diberi pakan sesuai perlakuan (booster II), kemudian pada hari ke-31--40 diberi pakan biasa. Pada hari ke-41 dilakukan sampling I dan dilanjutkan dengan sampling II \& III dengan interval 5 hari. Lima hari dari sampling terakhir dilakukan uji tantang dengan satu jenis bakteri patogen yaitu Aeromonas hydrophila (isolat yang digunakan pada percobaan I). Infeksi dilakukan melalui penyuntikan intraperitoneal pada konsentrasi $10^{8}$ cfu sebanyak $0,2 \mathrm{~mL}$ dan pengamatan berlangsung selama 7 hari

Pengamatan terhadap pengaruh pemberian perlakuan dilakukan melalui pengambilan darah yang dilakukan secara cardiac puncture dengan menggunakan syringe vol. $1,0 \mathrm{~mL}$. Secara ringkas, prosedur pengamatan adalah sebagai berikut: Sebagian dari darah hasil bleeding disimpan dalam tabung eppendorf dan diproses secara hematologis untuk mendapatkan serum darah yang akan digunakan untuk mengetahui ada-tidaknya reaksi silang (cross-reactivity) terhadap patogen potensial melalui uji titer antibodi. Pengamatan titer antibodi dilakukan dengan teknik aglutinasi langsung dalam objek glass atau titertek plate 96-lubang menurut metode yang dikembangkan oleh Carpenter (1975). Pengamatan terhadap sistem kekebalan non-spesifik dilakukan terhadap nilai indeks fagositosis menurut 
Tabel 1. Jadwal perlakuan selama percobaan potensi Saccharomyces cerevisiae sebagai imunostimulan pada kodok benggala

Table 1. Treatment time schedule of immunostimulant Saccharomyces cerevisiae application to induce the frog immune response

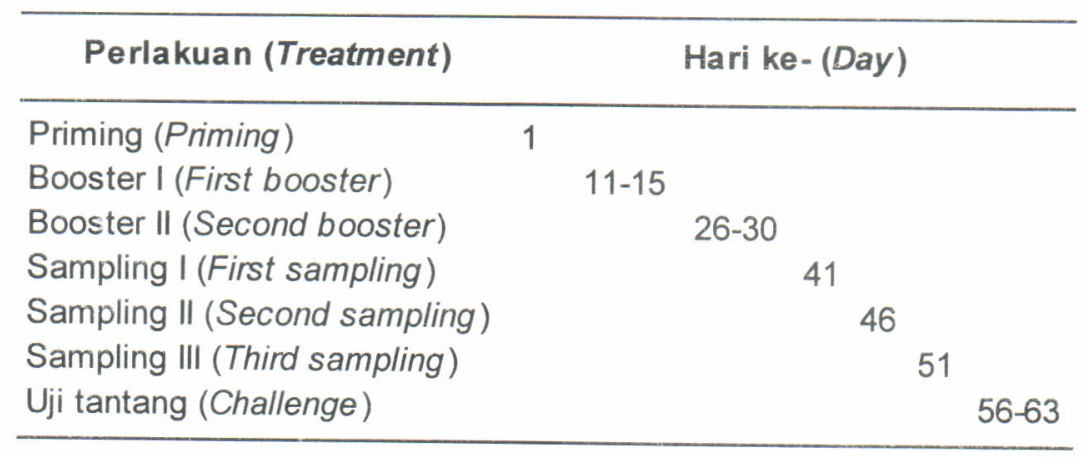

metode yang dikembangkan oleh Anderson \& Siwicki (1993) dengan menggunakan Staphylococcus aureus sebagai organisme model dan pengamatan diferensial leukosit dilakukan menurut metode Wedemeyer \& Yasutake (1989)

\section{HASIL DAN BAHASAN}

\section{Respon histopatologis tubuh kodok terhadap infeksi bakteri patogen}

Hasil identifikasi terhadap isolat bakteri uji yang diambil dari bagian luka kodok diketahui bahwa bakteri tersebut adalah jenis Aeromonas hydrophila dengan karakter: gram negatif, berbentuk batang pendek, bergerak atau memiliki sifat motil, koloni berwarna krem, bersifat katalase, mampu membentuk gas glukose, bersifat oksidatif-fermentatif, dan menunjukkan hasil positif pada uji cytocrom oxidase, acid glukose, ornithin, arginin, dan TSIA.

Gejala klinis setelah diinfeksi secara buatan menunjukkan adanya respon: nafsu makan menurun drastis dan lemah. Sedangkan pada kelompok kontrol tetap memperlihatkan respon yang normal, nafsu makan normal, serta tidak terdapat luka pada lokasi tempat injeksi. Munculnya luka pada kodok uji hanya terjadi pada kelompok yang diinfeksi bakteri dosis $10^{8}$ cfu/ekor dan hal tersebut mulai terjadi pada hari kedua setelah penyuntikan, namun luka tersebut akhirnya berangsur-angsur mengalami proses penyembuhan.

Hingga akhir pengamatan yang dilakukan selama 15 hari sejak proses infeksi, hanya ditemukan 2 ekor kodok yang mengalami kematian, dan keduanya terjadi pada kelompok yang diinfeksi bakteri dosis tinggi. Kematian terjadi di antara hari ke-3 hingga ke-6 setelah proses infeksi, namun dari ke-2 spesimen kodok yang mati tersebut tidak dijumpai adanya gejala klinis yang spesifik berdasarkan pengamatan secara visual. Sedangkan dari hasil pengamatan histopatologis terdapat indikasi adanya kerusakan pada organ hati maupun ginjal. Kerusakan jaringan sebagai respon histologis tersebui mulai ditemukan pada saat sampling ke-2 hingga akhir percobaan pada kelompok yang diinfeksi bakteri.

Kerusakan yang terjadi pada hati berupa degenerasi lemak yang ditandai dengan terbentuknya vakuola di antara sel hati, degenerasi pigmen (mela-nosis) dan nekrosis pada sel pembentuknya. Indikasi adanya kerusakan jaringan hati yang diduga akibat infeksi buatan dapat dilihat pada Gambar 1. Roberts (1978) menyatakan bahwa degenerasi lemak merupakan penggelembungan inti sel oleh tetesan lemak dan disebabkan oleh adanya pengendapan dari ceroid atau lipofusin akibat penyerbuan makrofag terhadap benda asing. Degenerasi pigmen ditandai dengan adanya gumpalan warna hitam terutama pada inti sel hati, sehingga nampak berukuran lebih besar dibandingkan dengan ukuran sel normal. Melanosis yang terbentuk diduga sebagai akibat dari respon seluler (monosit) terhadap bakteri, dan hasil dari aktivitas seluler ini terakumulasi membentuk gumpalan hitam pada inti sel. Nekrosis ditandai dengan pengerutan inti sel dan warna inti cenderung menghitam (piknosis), meluruhnya membran inti dan fragmentasi kromatin inti (kariorexis) dan struktur inti menjadi tidak beraturan serta berwarna hitam (kariolisis) (Roberts, 1978).

Kerusakan yang terjadi pada jaringan ginjal sebagian besar adalah terjadinya degenerasi lemak dan nekrosis. Nekrosis terlihat pada glomerulus, di mana dinding sel glomerulus tersebut pecah akibat adanya reaksi terhadap infeksi bakteri. Indikasi adanya kerusakan jaringan ginjal yang diduga akibat infeksi buatan dapat dilihat pada Gambar 2. Hanson \& Martha (1983) menyatakan bahwa infeksi bakteri dapat mengakibatkan kematian, kerusakan sel dan fungsinya, serta perubahan keragaan, sedangkan degenerasi lemak dan piknosis pada tubuh ginjal akan berpengaruh terhadap aktivitas ekskresi dan keseimbangan osmoregulasi. 
Tabel 2. Kerusakan histologis pada organ hati dan ginjal kodok yang diinfeksi dengan bakteri Aeromonas hydrophila

Table 2. Histological changes of the frog's liver and kidney after infected by Aeromonas hydrophila bacterin artificially

\begin{tabular}{|c|c|c|c|c|}
\hline \multirow{2}{*}{$\begin{array}{l}\text { Organ } \\
\text { Tissue }\end{array}$} & \multirow[b]{2}{*}{$\begin{array}{l}\text { Pengamatan ke- } \\
\text { Sampling }\end{array}$} & \multicolumn{3}{|c|}{ Dosis bakteri (Bacterial doses) } \\
\hline & & $\begin{array}{l}\text { Kontrol } \\
\text { Control }\end{array}$ & $\begin{array}{l}10^{6} \mathrm{cfu} / \mathrm{ekor} \\
10^{6} \mathrm{cfu} / \text { frog }\end{array}$ & $\begin{array}{l}10^{8} \mathrm{cfu} / \mathrm{e} \text { kor } \\
10^{8} \mathrm{cfu} / \mathrm{frog}\end{array}$ \\
\hline \multirow[b]{2}{*}{ Hati } & 1 & Normal & Normal & Normal \\
\hline & II & $\begin{array}{l}\text { Normal } \\
\text { Normal } \\
\text { Normal }\end{array}$ & $\begin{array}{c}\text { Normal } \\
\text { Mel+deg. lem+pik } \\
\text { Mel+fat deg. }+ \text { pik }\end{array}$ & $\begin{array}{c}\text { Nomal } \\
\text { Mel+deg. lem+pik } \\
\text { Mel+fat deg. +pik }\end{array}$ \\
\hline \multirow[t]{3}{*}{ Liver } & III & $\begin{array}{l}\text { Normal } \\
\text { Normal }\end{array}$ & $\begin{array}{l}\text { Mel+deg. lem+pik } \\
\text { Mel+fat deg. }+ \text { pik }\end{array}$ & $\begin{array}{l}\text { Mel+deg. lem+pik } \\
\text { Mel+fat deg. }+ \text { pik }\end{array}$ \\
\hline & IV & $\begin{array}{l}\text { Normal } \\
\text { Normal }\end{array}$ & $\begin{array}{l}\text { Mel+deg. lem+pik } \\
\text { Mel+fat deg. +pik }\end{array}$ & $\begin{array}{l}\text { Mel+deg. lem+pik } \\
\text { Mel+fat deg. +pik }\end{array}$ \\
\hline & V & $\begin{array}{l}\text { Normal } \\
\text { Normal }\end{array}$ & $\begin{array}{l}\text { Mel+deg. lem+pik } \\
\text { Mel+fat deg. }+ \text { pik }\end{array}$ & $\begin{array}{l}\text { Mel+deg. lem+pik } \\
\text { Mel+fat deg. + pik }\end{array}$ \\
\hline \multirow{3}{*}{ Ginjal } & 1 & Normal & Normal & Normal \\
\hline & & Normal & Normal & Normal \\
\hline & $\|$ & $\begin{array}{l}\text { Normal } \\
\text { Normal }\end{array}$ & $\begin{array}{l}\text { Deg. lem+pik } \\
\text { Fat deg. }+ \text { pik }\end{array}$ & $\begin{array}{l}\text { Deg. lem+pik } \\
\text { Fat deg. + pik }\end{array}$ \\
\hline \multirow[t]{6}{*}{ Kidney } & III & Normal & Deg. lem+pik & Deg. lem+pik \\
\hline & & Normal & Fat deg. + pik & Fat deg. + pik \\
\hline & IV & Normal & Deg. lem+pik & Deg. lem+pik \\
\hline & & Normal & Fat deg. + pik & Fat deg. + pik \\
\hline & V & Normal & Deg. lem+pik & Deg. lem+pik \\
\hline & & Normal & Fat deg. + pik & Fat deg. +pik \\
\hline
\end{tabular}

Keterangan (Notes): $\quad$ Mel = melanosis (melanozation), Deg. Lem = degenerasi lemak (fat degeneration), dan Pik = piknosis (piknotic)
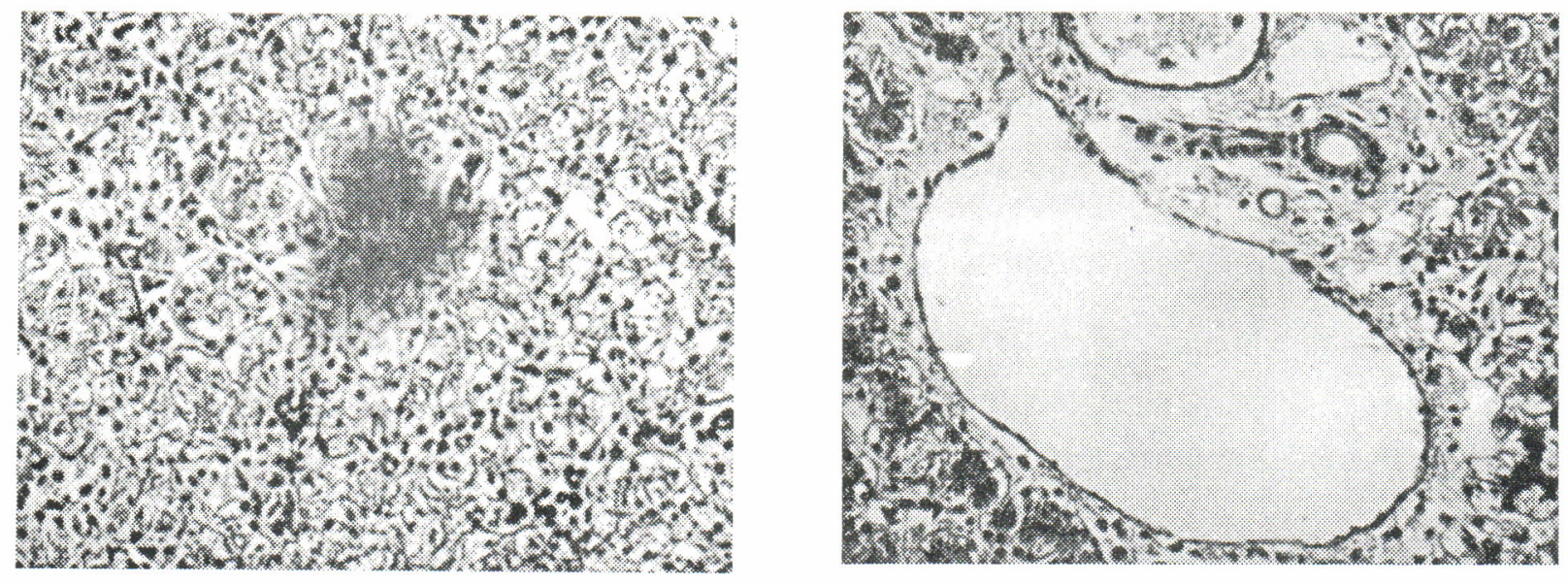

Gambar 1. Jaringan hati kodok yang diinfeksi bakteri Aeromonas hydrophila (kiri) dan kontrol (kanan). Anak panah menunjukkan sel yang mengalami melanosis

Figure 1. Frog's liver tissue infected by Aeromonas hydrophila artificially (left) and control liver tissue (right). Arrow shows melanotic cells 

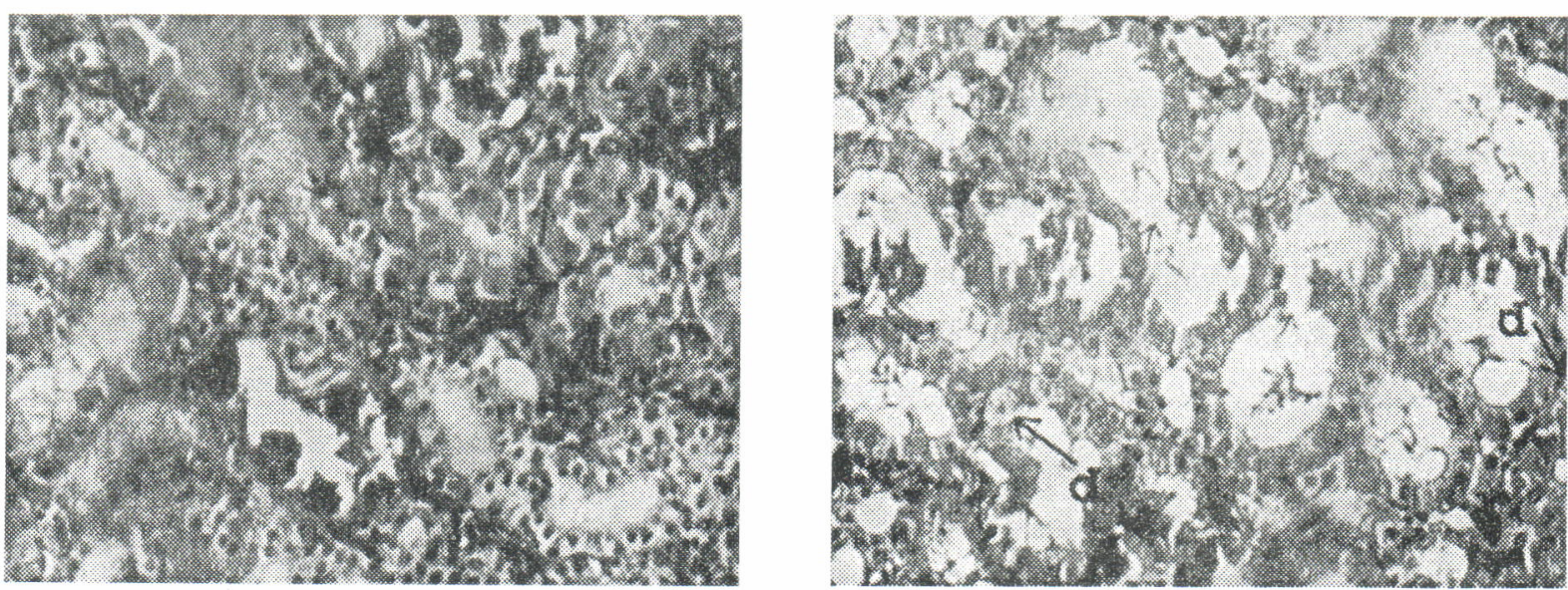

Gambar 2. Jaringan ginjal kodok yang diinfeksi bakteri Aeromonas hydrophila (kiri) dan kontrol (kanan). Dalam lingkaran merupakan sel glomerulus yang mengalami nekrosa

Figure 2. Frog's kidney tissue infected by Aeromonas hydrophila artificially (left), and control kidney tissue (right). Massive glomerulus necrotic cells inside circle

Potensi Saccharomyces cerevisiae sebagai imunostimulan

Diferensial leukosit sering digunakan sebagai salah satu parameter hematologis untuk mengetahui status kesehatan dan kemampuan pertahananan tubuh (pertahanan seluler) terhadap infeksi jasad patogen. Nilai rata-rata proporsi 4 jenis sel leukosit (limfosit, monosit, netrofil, dan trombosit) yang diamati dari kodok uji selama 3 kali sampling disajikan pada Tabel 3, dan gambaran dari masing-masing sel leukosit tersebut dapat dilihat pada Gambar 3. Pada Tabel 3 terlihat bahwa proporsi jumlah sel limfosit dan netrofil untuk kelompok yang diberi perlakuan menunjukkan nilai yang lebih tinggi dibandingkan dengan kontrol, sedangkan proporsi jumlah sel monosit dan trombosit

Tabel 3. Rata-rata proporsi nilai diferensial leukosit (limfosit, monosit, netrofil, dan trombosit) darah kodok (Rana catesbeiana Shaw) yang diberi imunostimulan (Saccharomyces cerevisiae) dan kontrol

Table 3. Mean of differential leucocyte (lymphocyte, monocyte, netrophyl, and trombocyte) proportion value of bullfrog's (Rana catesbeiana Shaw) blood were given immunostimulant (Saccharomyces cerevisiae) and control

\begin{tabular}{lcccc}
\hline Sampling/Dosis (Sampling/dose) & $\begin{array}{c}\text { Limfosit } \\
\text { Lymphocyte }\end{array}$ & $\begin{array}{c}\text { Monosit } \\
\text { Monocyte }\end{array}$ & $\begin{array}{c}\text { Netrofil } \\
\text { Netrophyl }\end{array}$ & $\begin{array}{c}\text { Trombosit } \\
\text { Trombocyte }\end{array}$ \\
\hline Pertama (First) & & & & \\
$500 \mathrm{mg} / \mathrm{kg}$ pakan $(500 \mathrm{mg} / \mathrm{kg}$ feed) & $92.33 \pm 3.68$ & $4.33 \pm 2.56$ & $5.17 \pm 2.08$ & $0.17 \pm 0.28$ \\
$750 \mathrm{mg} / \mathrm{kg}$ pakan $(750 \mathrm{mg} / \mathrm{kg}$ feed) & $84.33 \pm 12.91$ & $6.5 \pm 5.68$ & $8.5 \pm 6.08$ & $0.67 \pm 1.15$ \\
$1,000 \mathrm{mg} / \mathrm{kg}$ pakan $(1,000 \mathrm{mg} / \mathrm{kg}$ & $86.83 \pm 9.31$ & $6.83 \pm 5.6$ & $6.33 \pm 3.75$ & $0.00 \pm 0.00$ \\
kontrol (control) & $84.33 \pm 3.62$ & $7.67 \pm 1.26$ & $4.33 \pm 1.04$ & $3.67 \pm 1.89$ \\
\hline Kedua (Second) & & & & \\
$500 \mathrm{mg} / \mathrm{kg}$ pakan $(500 \mathrm{mg} / \mathrm{kg}$ feed) & $92.5 \pm 7.5$ & $6.33 \pm 2.47$ & $5.0 \pm 2.18$ & $2.17 \pm 3.75$ \\
$750 \mathrm{mg} / \mathrm{kg}$ pakan $(750 \mathrm{mg} / \mathrm{kg}$ feed) & $89.0 \pm 3.61$ & $6.83 \pm 0.76$ & $8.17 \pm 0.76$ & $2.0 \pm 3.46$ \\
$1,000 \mathrm{mg} / \mathrm{kg}$ pakan $(1,000 \mathrm{mg} / \mathrm{kg}$ & $90.5 \pm 3.28$ & $4.33 \pm 1.04$ & $6.17 \pm 1.53$ & $1.0 \pm 1.73$ \\
kontrol (control) & $81.67 \pm 3.82$ & $7.5 \pm 5.41$ & $4.83 \pm 3.33$ & $6.0 \pm 5.07$ \\
\hline Ketiga (Third) & & & & \\
$500 \mathrm{mg} / \mathrm{kg}$ pakan $(500 \mathrm{mg} / \mathrm{kg} \mathrm{feed)}$ & $90.17 \pm 4.25$ & $6.5 \pm 1.61$ & $5.67 \pm 1.89$ & $0.5 \pm 0.00$ \\
$750 \mathrm{mg} / \mathrm{kg}$ pakan $(750 \mathrm{mg} / \mathrm{kg} \mathrm{feed)}$ & $88.33 \pm 12.05$ & $6.03 \pm 7.08$ & $7.33 \pm 2.93$ & $3.33 \pm 3.8$ \\
$1,000 \mathrm{mg} / \mathrm{kg}$ pakan $(1,000 \mathrm{mg} / \mathrm{kg}$ & $89.67 \pm 7.51$ & $6.83 \pm 3.25$ & $5.33 \pm 4.01$ & $0.17 \pm 0.46$ \\
kontrol (control) & $82.5 \pm 9.64$ & $7.83 \pm 6.66$ & $5.0 \pm 5.57$ & $1.67 \pm 2.89$ \\
\hline
\end{tabular}




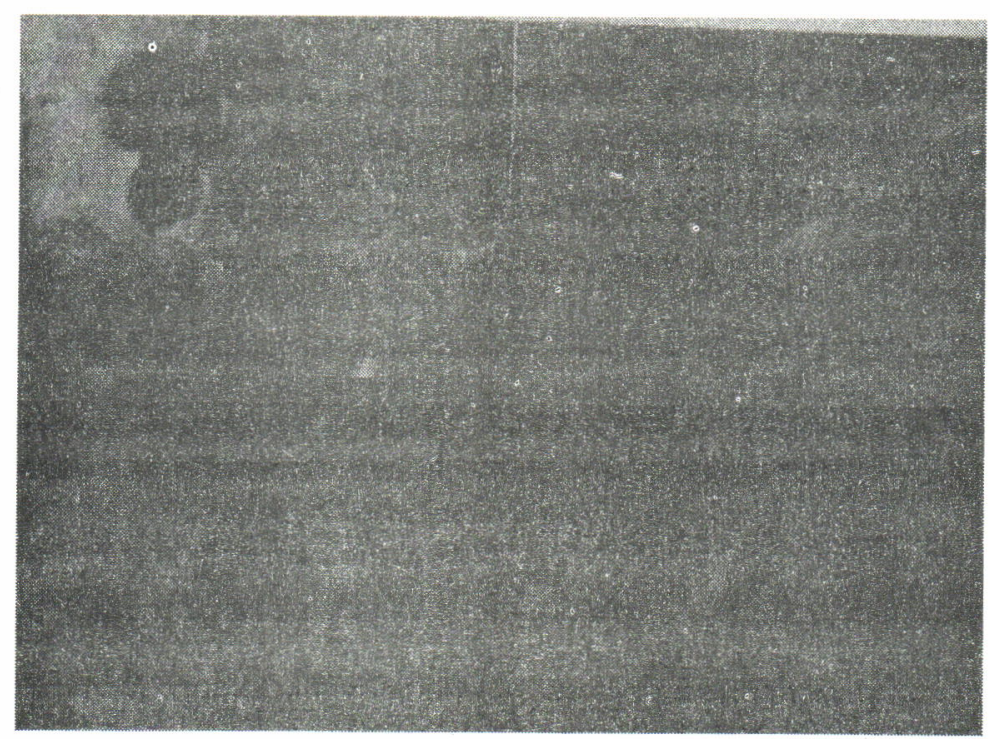

Gambar 3. Jenis-jenis leukosit pada kodok (Rana catesbeiana Shaw). Limfosit (L), Monosit (M), Netrofil (N), dan Trombosit (T) dengan pewarnaan giemsa pada pembesaran 1,000x

Figure 3. Leucocyte types of bullfrog (Rana catesbeiana Shaw). Lymphocyte (L), Monocyte (M), Netrophyl $(N)$, and Trombocyte $(T)$ with giemsa stain at 1,000x magnification

nampaknya menunjukkan hal yang sebaliknya, yaitu relatif tinggi pada kelompok kontrol dibandingkan dengan kelompok perlakuan. Lebih tingginya proporsi sel limfosit dan netrofil pada kelompok perlakuan mengindikasikan bahwa imunostimulan tersebut berperan dalam meningkatkan ketahanan non-spesifik tubuh kodok, hal ini didasarkan pada fungsi dari kedua jenis sel darah tersebut. Secara statistik tidak menunjukkan perbedaan yang nyata $(P<0,05)$, baik antar perlakuan maupun antara perlakuan dengan kontrol. Secara visual terlihat adanya peningkatan proporsi sel-sel fungsional (limfosit dan netrofil) pada kelompok perlakuan.

Sel limfosit berfungsi menyediakan zat kebal untuk pertahanan tubuh (Dellman \& Brown, 1989); ditemukan dalam jumlah yang cukup besar, meskipun pada saat infeksi terjadi penurunan. Peningkatan jumlah limfosit pada kelompok perlakuan (Tabel 3) diduga sebagai akibat dari pemberian imunostimulan, hal ini sesuai dengan hipotesis Raa et al. (1992) bahwa pemberian imunostimulan akan menstimulir proses produksi lisosim dan komplemen yang akan mengaktifkan limfosit B untuk berdiferensiasi sehingga akan lebih aktif dalam memproduksi antibodi spesifik.

Menurut Dellman \& Brown (1989), fungsi netrofil tidak hanya mencapai dan menyerang bahan asing yang masuk ke dalam tubuh, tetapi menjelang kematian membantu meningkatkan pengumpulan makrofag di tempat terjadinya infeksi, sehingga makrofag lebih mudah untuk menghancurkan partikel asing. Makrofag ini mampu memiliki aktivitas fagositosis yang tahan lama, mengolah antigen dalam persiapan untuk tanggap kebal dan memberi kontribusi langsung pada perbaikan jaringan yang rusak dengan membuang jaringan yang sudah mati, ataupun yang sedang mengalami proses kematian dan yang telah rusak.

Fungsi utama netrofil adalah penghancuran bahan asing melalui proses fagositosis, yaitu kemotaksis di mana sel bermigrasi menuju partikel, perlekatan partikel pada sel, penelanan partikel oleh sel dan penghancuran partikel oleh enzim lisosim di dalam fagolisosom (Tizard, 1988). Keluarnya netrofil dari pembuluh darah pada saat terjadinya infeksi disebabkan karena adanya pengaruh rangsangan kimiawi eksternal atau kemotaksis. Netrofil ini merupakan garis pertahanan pertama yang bergerak cepat ke arah bahan asing dan menghancurkannya, tetapi tidak mampu bertahan lama. Biasanya netrofil hanya menghancurkan tuntas setiap bahan asing yang ditelan dan tidak mengolah antigen sebagai persiapan guna disajikan pada sel peka antigen (Tizard, 1988).

Peningkatan proporsi netrofil pada kelompok perlakuan (Tabel 3) diduga akibat distimulasi oleh materi imunostimulan, sehingga aktivitas produksi oleh organ pembentuk sel tersebut kian meningkat. Pada mamalia, netrofil merupakan sel fagositik dan akan nampak sangat cepat di sekitar tempat yang mengalami luka. Pada ikan yang mengalami luka akibat infeksi bak-teri juga ditemukan adanya migrasi dan fagositosis oleh netrofil dan sel makrofag (Finn \& Nielson, 1971).

Proporsi monosit dan trombosit didapatkan relatif rendah pada kelompok perlakuan dibanding dengan kontrol (Tabel 3), hal ini mungkin terjadi sebagai respon keseimbangan hematologi terhadap 
peningkatan proporsi sel leukosit jenis lainnya, yaitu limfosit dan netrofil. Sel monosit diduga berperan sebagai sistem pertahanan kedua di mana sistem ini berlangsung lambat dan lama tetapi mampu melakukan fagositosis berulang-ulang (Tizard, 1988). Jumlah trombosit umumnya relatif rendah pada kelompok perlakuan dibandingkan dengan kontrol (Tabel 3). Hal ini diduga karena tidak adanya kodok yang terluka atau terinfeksi patogen. Seperti diketahui bahwa fungsi trombosit itu sendiri adalah untuk pembekuan darah saat terjadi luka dan mencegah kehilangan cairan tubuh pada kerusakan-kerusakan di permukaan kulit (Nabib \& Pasaribu, 1989); juga untuk menutup luka (Roberts, 1978).
Indeks fagositik dalam darah kodok yang dihitung terhadap sel fagosit fungsional menunjukkan bahwa pada kelompok yang diberi perlakuan terdeteksi ratarata lebih tinggi dibandingkan dengan kelompok kontrol. Fenomena ini merupakan indikator bahwa pada kelompok perlakuan memiliki kemampuan pertahanan non-spesifik yang lebih baik dibandingkan dengan kelompok kontrol. Rata-rata nilai indeks fagositik dari masing-masing perlakuan disajikan pada Tabel 4. Sedangkan hipotesa mekanisme aktivitas fagositik disajikan pada Gambar 4.

Uji statistik terhadap nilai rata-rata aktivitas fagositik pada selang kepercayaan $95 \%$ menunjukkan adanya perbedaan yang nyata $(P<0,05)$ antara perlakuan

Tabel 4. Rata-rata nilai indeks fagositik (\%) sel fagosit fungsional darah kodok (Rana catesbeiana Shaw) yang diberi imunostimulan (Saccharomyces cerevisiae) dan kontrol

Table 4. Mean of phagocytic index value (\%) of bullfrog's (Rana catesbeiana Shaw) blood cell phagocyte was given immunostimulant (Saccharomyces cerevisiae), and control

\begin{tabular}{|c|c|c|c|c|}
\hline \multirow{2}{*}{$\begin{array}{l}\text { Sampling } \\
\text { Sampling }\end{array}$} & \multicolumn{4}{|c|}{ Perlakuan (Treatment) } \\
\hline & $\begin{array}{c}500 \mathrm{mg} / \mathrm{kg} \text { pakan } \\
500 \mathrm{mg} / \mathrm{kg} \text { feed }\end{array}$ & $\begin{array}{c}750 \mathrm{mg} / \mathrm{kg} \text { pakan } \\
750 \mathrm{mg} / \mathrm{kg} \text { feed }\end{array}$ & $\begin{array}{c}1000 \mathrm{mg} / \mathrm{kg} \text { pakan } \\
1000 \mathrm{mg} / \mathrm{kg} \text { feed }\end{array}$ & $\begin{array}{l}\text { Kontrol } \\
\text { Control }\end{array}$ \\
\hline Pertama (First) & $16.5 \pm 1.80 a$ & $18.83 \pm 3.05 a$ & $21.5 \pm 3.77 a$ & $8.5 \pm 5.77 b$ \\
\hline Kedua (Second) & $13.67 \pm 1.15 a$ & $17.33 \pm 1.04 a$ & $14.33 \pm 3.17 a$ & $6.83 \pm 1.04 b$ \\
\hline Ketiga (Third) & $14.67 \pm 6.11 \mathrm{a}$ & $18.17 \pm 3.25 a$ & $16.00 \pm 6.56 a$ & $5.5 \pm 2.29 b$ \\
\hline
\end{tabular}

Nilai yang diikuti huruf yang sama dalam kolom yang sama menunjukkan tidak berbeda nyata $(P>0,05)$ Value followed by similar superscripts in the same column are not significantly different) $(P>0.05)$

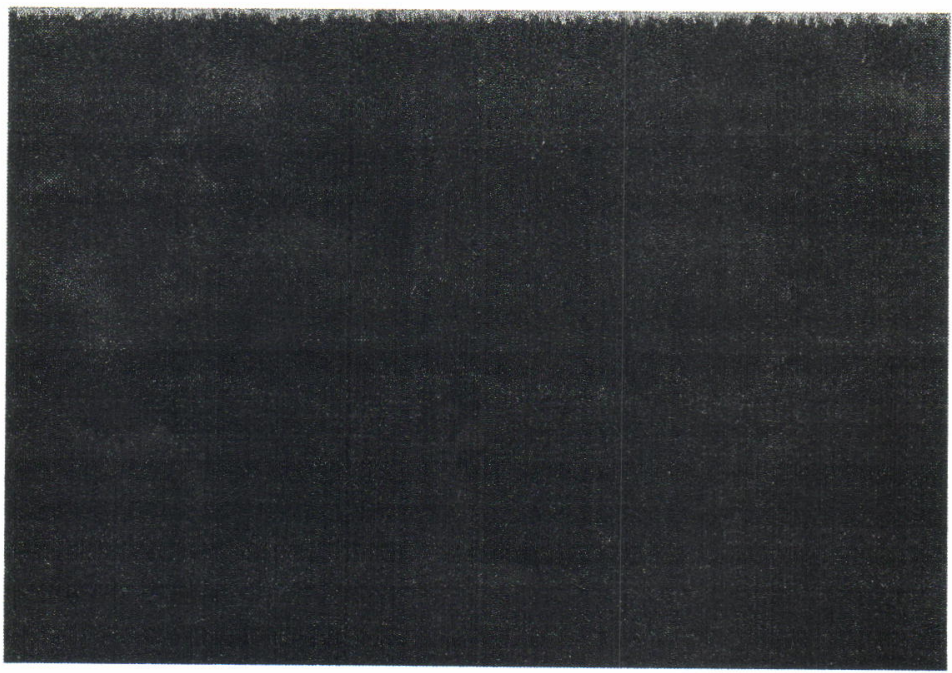

Gambar 4. Hipotesis mekanisme proses fagositosis pada sel fungsional darah kodok (Rana catesbeiana Shaw). 1 = Sel tanpa bakteri, 2 = Proses pendekatan, 3 = Proses penempelan, dan $4=$ Proses penelanan. (Raa et al., 1992)

Figure 4. Hypotetical mechanism of phagocytic activity of bullfrog (Rana catesbeiana Shaw) phagocyte blood cell. 1 = cells without bacteria, 2 = approaching process, $3=$ attaching process, and $4=$ attacking process. (Raa et al., 1992) 
dengan kontrol. Namun nilai aktivitas fagositosis pada kelompok kodok yang diberi imunostimulan untuk ketiga dosis perlakuan tidak menunjukkan adanya perbedaan yang nyata, hal ini ditunjukkan oleh hasil uji lanjut BNJ.

Berdasarkan indikasi peningkatan aktivitas fagositik yang terjadi, nampaknya pemberian imunostimulan pada dosis yang lebih tinggi tidak memberikan efek simultan terhadap peningkatan kekebalan non-spesifik. Hal ini sering terjadi dalam aplikasi imunologi, di mana pemberian antigen dalam jumlah yang tidak optimal (terlalu rendah atau terlalu tinggi) dapat memberikan efek yang kurang baik dan bahkan dapat bersifat immunospressive, sehingga mengurangi atau bahkan menghilangkan efektivitasnya, meskipun antigen tersebut memiliki potensi imunogenik yang tinggi. Taukhid et al. (2000) mendapatkan bahwa pemberian imunostimulan (Lipopolisakarida) secara intraperitoneal pada $R$. Catesbeiana sebanyak 50 mg/ekor diperoleh nilai aktivitas fagositik yang lebih tinggi dan stabil dibandingkan dengan kelompok yang diberi dosis lebih tinggi maupun kelompok kontrol. Sedangkan Crumlish \& Inglish (1999) melaporkan bahwa pemberian imunostimulan (b-glucan) secara intraperitoneal sebanyak $100 \mathrm{~mL}$. (w/v) pada R. rugulosa dengan bobot tubuh rata-rata 40 g/ekor memberikan tingkat sintasan yang sangat signifikan dibandingkan dengan kontrol setelah diuji tantang dengan bakteri Aeromonas hydrophila patogen.

Dasar pendekatan penggunaan imunostimulan sebagai materi biologis untuk menginduksi kekebalan non-spesifik pada mulanya adalah untuk terapi kanker, karena materi tersebut diketahui mampu mengaktivasi sel makrofag, sel limfosit $T$ dan $B$, dan sel pembunuh alami; sehingga akan meningkatkan kemampuan tubuh untuk menghancurkan sel-sel tumor. Aktivitas tersebut juga akan meningkatkan ketahanannya terhadap infeksi jasad viral, bakterial dan parasitik (Azuma \& Jolles, 1987).

Aktivitas fagositik merupakan salah satu manifestasi respon seluler pada organisme terhadap kehadiran partikel asing. Peningkatan aktivitas fagositik yang cukup nyata pada kelompok perlakuan (Tabel 4) diduga sebagai akibat dari pemberian imunostimulan, karena menurut Raa et al. (1992), imunostimulan dapat memacu proses opsonin sel makrofag dan leukosit terhadap partikel asing.

Raa et al. (1992) berhasil menguak kemampuan imunostimulan (MacroGard) dalam menstimulir produksi sel makrofag (interleukin-1-like hormone) pada ikan secara in vitro. Sel tersebut merupakan signal molekul yang diketahui berperan dalam proses aktivasi sel limfosit $T$ yang berfungsi melipatgandakan dan memproduksi lebih banyak interferon sebagai aktivator sel makrofag.

Fletcher (1982) dan Lamers (1985) menduga beberapa elemen yang terlibat dalam mekanisme pertahanan non-spesifik pada ikan dan vertebrata lainnya, yaitu terdiri atas sel fagositik, netrofil dan makrofag, komplemen, lisosim, protein, C-reactive, interferon, dan transferin. Sedangkan Crumlish (Percom, 2000) berdasarkan pengamatannya terhadap sel-sel fagosit fungsional pada kodok ( $R$. rugulosa) menyatakan bahwa sebagian besar sel leukosit kodok memilki kemampuan fagositik terhadap partikel asing.

Pengamatan terhadap kemungkinan adanya peran imunostimulan terhadap peningkatan induksi kekebalan spesifik (titer antibodi), menunjukkan bahwa pemberian imunostimulan nampaknya berperan juga dalam upaya memfasilitasi produksi materi kekebalan spesifik. Fenomena ini nampaknya sedikit-banyak turut mendukung hipotesis Raa et al. (1992) yang menyatakan bahwa imunostimulan tidak hanya berfungsi sebagai aktivator mekanisme pertahanan non-spesifik, namun juga turut memfasilitasi proses produksi lisosim dan komplemen yang akan mengaktifkan limfosit B untuk berdiferensiasi bagi keperluan produksi antibodi spesifik. Nilai rata-rata titer antibodi dalam serum darah kodok uji yang dilakukan dengan teknik aglutinasi langsung disajikan pada Tabel 5.

Pada tabel tersebut terlihat bahwa nilai rata-rata titer antibodi kelompok kodok yang diberi imunostimulan lebih tinggi dibandingkan dengan kontrol, dan secara statistik menunjukkan perbedaan yang nyata pada selang kepercayaan $95 \%(P>0,05)$. Raa et al. (1992) menyatakan bahwa imunostimulan tidak hanya berfungsi sebagai aktivator mekanisme pertahanan non-spesifik, namun juga turut memfasilitasi proses produksi lisosim dan komplemen yang akan mengaktifkan limfosit B untuk berdiferensiasi memproduksi antibodi spesifik.

Berdasarkan hasil uji tantang terhadap bakteri Aeromonas hydrophila aktif yang dilakukan satu minggu setelah sampling terakhir, tidak diperoleh informasi yang jelas. Karena hingga akhir pengamatan yang dilakukan selama satu minggu sejak proses infeksi, tidak ada satu ekor pun kodok uji yang mengalami kematian. Sedangkan gejala klinis umum yang terlihat pada kodok-kodok uji antara lain kurang nafsu makan, lamban, dan lemah. Kemungkinan hal ini dapat terjadi karena beberapa faktor: 1) Populasi kodok uji yang digunakan pada percobaan ini sebelumnya pernah terpapar oleh bakteri $A$. hydrophila, sehingga di dalam tubuhnya telah terbentuk antibodi spesifik yang diperoleh secara alamiah, hal ini juga terlihat pada hasil pengukuran titer antibodi, di mana semua kelompok kodok memiliki serum darah yang 
Tabel 5. Rata-rata nilai titer antibodi serum darah kodok (Rana catesbeiana Shaw) yang diberi imunostimulan (Saccharomyces cerevisiae) dan kontrol

Table 5. Mean of antibody titres of bullfrog's (Rana catesbeiana Shaw) blood serum were given immunostimulant (Saccharomyces cerevisiase) and control

\begin{tabular}{lcccc}
\hline \multirow{2}{*}{$\begin{array}{c}\text { Percontoh } \\
\text { (Sampling) }\end{array}$} & \begin{tabular}{c}
$500 \mathrm{mg} / \mathrm{kg}$ pakan \\
\cline { 2 - 5 }
\end{tabular} & $\begin{array}{c}\mathbf{7 5 0} \mathbf{~ m g / k g} \text { pakan } \\
\mathbf{7 5 g} \mathbf{~} \mathbf{k g} / \mathbf{k g} \text { feed }\end{array}$ & $\begin{array}{c}1.000 \mathrm{mg} / \mathrm{kg} \text { pakan } \\
\mathbf{1 , 0 0 0 ~} \mathbf{~ g} / \mathbf{k g} \text { feed }\end{array}$ & $\begin{array}{c}\text { Kontrol } \\
\text { Control }\end{array}$ \\
\hline Pertama (First) & $3.207 \pm 0.174^{\mathrm{a}}$ & $3.408 \pm 0.301$ & $2.906 \pm 0.174$ & $2.506 \pm 0.000$ \\
Kedua (Second) & $3.200 \pm 0.013$ & $3.420 \pm 0.000$ & $3.207 \pm 0.174$ & $2.605 \pm 0.174$ \\
Ketiga (Third) & $3.308 \pm 0.174$ & $3.207 \pm 0.174$ & $3.307 \pm 0.000$ & $2.605 \pm 0.174$ \\
\hline
\end{tabular}

Angka-angka tersebut merupakan hasil transformasi log nilai titer +1 , dan angka yang diikuti huruf yang sama menunjukkan tidak berbeda nyata $(P>0,05)$

The numbers above have been transformed into log (titre +1$)$, and superscript in columns followed by the same letter are not significantly different) $(P>0.05)$

bereaksi positif terhadap antigen tersebut. 2) Faktor host spesific target, meskipun isolat bakteri $A$. hydrophila yang digunakan dalam proses uji tantang diisolasi dari kodok sakit, namun patut diduga bahwa jenis bakteri tersebut bukan satu-satunya primary pathogen yang mampu menimbulkan gejala red leg. Hasil isolasi bakteri dari beberapa kodok sakit dengan gejala serupa yang dilakukan oleh Somsiri \& Soontornvit (2000) ternyata ditemukan lebih dari satu jenis, yaitu bakteri Aeromonas spp., Achromobacter $\mathrm{sp}$., Citrobacter freundii, Flexibacter columnaris, Pseudomonas spp., Proteus spp., Serratia sp., Staphylococcus sp., dan Streptococcus.

\section{KESIMPULAN DAN SARAN}

* Infeksi buatan tubuh kodok terhadap bakteri Aeromonas hydrophila yang dilakukan melalui penyuntikan secara intra muskular (IM) pada konsentrasi $10^{6} \mathrm{cfu}$ dan $10^{8} \mathrm{cfu}$ menunjukkan bahwa infeksi bakteri model pada konsentrasi tersebut tidak menyebabkan respon histologis yang serius dan tidak mengakibatkan kematian hewan uji.

* Pemberian imunostimulan dalam bentuk ekstrak Saccharomyces cerevisiae yang diberikan melalui perendaman dan dilanjutkan dengan pemberian melalui pakan dapat meningkatkan respon kekebalan tubuh kodok.

* Imunoterapi merupakan alternatif strategi penanggulangan penyakit yang prospektif sebagai tindakan pencegahan, namun dari kenyataan begitu variatifnya patogen penyebab penyakit pada kodok budi daya; maka perlu adanya identifikasi patogen yang dilakukan secara periodik dari spesimenspesimen kodok sakit yang dilanjutkan dengan pengujian efektivitas penggunaan obat-obatan/ antibiotik sebagai upaya tindakan kuratif.

\section{DAFTAR PUSTAKA}

Anderson, D.P. 1974. Fish Immunology. In Disease of Fishes. Edited by Snieszko, J.F. and H.R. Axelrod. TFH Publ. Hongkong. 318 pp.

Anderson, D.P. and A.K. Siwicki. 1993. Basic hematology and serology for fish health programs. Asian Fisheries Society. 26 pp.

Azuma, I. and G. Jolles. 1987. Development of immunostimulants in Japan. In: Immunostimulants now and tomorrow. Japan Sci. Soc. Press, Tokyo and Spring Verlag, Berlin. p. 41--56.

Carpenter, P.L. 1975. Immunology and Serology. Third Ed. W.B. Saunders. Co, Philadelphia. 296 pp.

Cowan and Steells. 1993. Manual for the Identification of Medical Bacteria (Edited by G.I. Barrow \& R.K.A. Feltham). Cambridge University Press. Cambridge. $317 \mathrm{pp}$.

Crumlish, M. and V. Inglish. 1999. Improved disease resistance in Rana rugulosa (Daudin) after b-glucan administration. Aquaculture Research, Blackwell Science Ltd. 30: 431--435.

Dellman, H.D. and E.M. Brown. 1989. Buku Teks Histologi Veteriner. Penerbit Universitas Indonesia. Jakarta. $279 \mathrm{pp}$

Finn, J.P. and N.O. Nielson. 1971. The inflammatory of rainbow trout. J. Fish Biol. 3: 463--478.

Fletcher, T.C. 1982. Non-specific defence mechanisms of fish. Dev. Comp. Immunol. 2: 123--132 (Suppl).

Hanson, R.P. and G. Martha. 1983. Animai Disease Control Regional Programs. The lowa State University Press, Ames, IOWA. 211 pp.

Lamers, C.H.J. 1985. The Reaction of the Immune System of Fish to Vaccination. Abstract of PhD thesis. Agricultural University Wageningen, Netherlands.

Kanchanakhan, S. U. Saduakdee, A. Kreethachat, and S. Chinabut. 2000. Isolation of A. FV3-like Iridovirus from a cutaneous ulceration and systemic inflammation with exuberant hematopoiesis or CSE dis- 
ease of Mundriyanto, H., Rusmaedi, dan $H$. Djajasewaka. 1993. Berbagai tipe kandang untuk pembesaran katak benggala (Rana catesbeiana Shaw). Prosiding Seminar Hasil Penelitian Perikanan Air Tawar 1992/1993. p. 266--270.

Nabib, R. dan F.H. Pasaribu. 1989. Patologi dan Penyakit Ikan. Dep Dik Bud. Dirjen Pendidikan Tinggi. PAU Bioteknologi. IPB. p. 37--41.

Kanchanakhan, S. 1998. An ulcerative disease of the cultured tiger frog, Rana tigrina in Thailand: virological examination. The Aquatic Animal Health Research Institute (AAHRI) Newsletter. Vol. 7 No. 2.

Kanchanakhan, S., U. Saduakdee, A. Kreethachat, and S. Chinabut. 2000. Isolation of A FV3-like Iridovirus from a cutaneous ulceration and systemic inflammation with exuberant hematopoiesis or CSE disease of cultured frog, Rana tigrina Cantor, in Thailand. The Aquatic Animal Health Research Institute (AAHRI) Newsletter. Vol. 9 No. 1, June 2000. p. 5--7.

Raa, J., G. Roerstad, R. Engstad, and B. Robertsen. 1992. The use of immunostimulants to increase resistance of aquatic organisms to microbial infections. In Diseases in Asian Aquaculture 1. Proceeding of the First Symposium on Diseases in Asian Aquaculture, 2629 November 1990, Bali, Indonesia. M. Shariff, R.P. Subasinghe and J.R. Arthur. (Eds.) Manila, Philippines, Fish Health Section, Asian Fisheries Society. p. $39-50$.
Roberts, R.J. 1978. Fish Pathology of Fish. lowa State University Press, Ames, lowa. p. 3--10.

Robertsen B., G. Rorstad., R. Engstad, and J. Raa. 1990. Enhancement of non-specific disease resistance in Atlantic Salmon, Salmo salar L., by a Glukan From Saccharomyces cerevisiae Cell Walls. Journal of Fish Disease 13: 391-400.

Somsiri, T. and S. Soontornvit. 2000. Bacterial diseases of cultured tiger frog (Rana tigerina). The Aquatic Animal Health Research Institute (AAHRI) Newsletter. Vol. 9 No. 1, June 2000. p. 3--5.

Subasinghe, R.P., U. Barg, and A. Tacon. 2000. Chemicals in Asian Aquaculture: Need, usage, issues, and challenges. Proceedings of the Meeting on the Use of Chemicals in Aquaculture in Asia. 20-22 May 1996, Tigbauan, Iloilo, Phillippines. JR. Arthur, CR LavillaPitogo, and RP Subasinghe. (Eds.) SEAFDEC Aquaculture Department 5021 Tigbauan, Iloilo, Phillippines. p. 1--5.

Tizard, I.R. 1988. An introduction to Veterinary immu nology. W.B. Saunders Company, Philadelphia. 240 pp

Thrusfield, M. 1986. Veterinary Epidemiology. Butterworth \& Co. L.td. Butterworth. Great Britain. 462 pp.

Wedemeyer, G.A. and W.T. Yasutake. 1989. Clinical methods for the assessment of the effects of environmental stress on fish health. Technical Report of Fisheries of the U.S. Fish and Wildlife Service. $18 \mathrm{pp}$. 